\title{
Rancang Bangun Kendali Jarak Jauh Robot Servis Berbasis Internet of Things
}

\author{
Adrie Sentosa, Dr. Ir. Djoko Purwanto, M.Eng., dan Rudy Dikairono, S.T., M.T. \\ Jurusan Teknik Elektro, Fakultas Teknologi Industri, Institut Teknologi Sepuluh Nopember (ITS) \\ Jl. Arief Rahman Hakim, Surabaya 60111 \\ e-mail: djoko@ee.its.ac.id, rudydikairono@ee.its.ac.id, adrie12@mhs.ee.its.ac.id
}

\begin{abstract}
Abstrak-Robot servis otonom, khususnya robot pembersih debu otonom, yang melakukan pekerjaan secara mandiri ketika pengguna tidak berada di rumah merupakan impian sebagian besar masyrakat. Berbagai perusahaan dan institusi penelitian telah melakukan usaha yang baik dalam merancang robot servis otonom. Robot servis otonom yang dikembangkan saat ini dikendalikan dengan tombol ataupun remote control berbasis inframerah. Hal ini menjadi permasalahan ketika pengguna tidak berada di lokasi robot servis sehingga pengguna tidak dapat memberikan perintah kepada robot servis secara langsung. Maka dari itu, dirancanglah kendali jarak jauh robot servis berbasis Internet of Things yang memungkinkan robot servis untuk dikendilakan pada jarak jauh. Robot servis akan diintegrasikan dengan divais android atau komputer berbasis internet untuk menggantikan fungsi remote control sehingga pengguna dapat melakukan perintah dimanapun mereka berada selama memiliki koneksi internet. Diharapkan dengan adanya rancang bangun kendali jarak jauh ini, pengguna menjadi lebih mudah dalam mengendalikan atau memberikan perintah kepada robot servis.
\end{abstract}

Kata Kunci-Kontrol Jarak Jauh, Robot Servis, Internet of Things

\section{PENDAHULUAN}

$\mathrm{D}$ ALAM bidang pelayanan domestik, penggunaan tenaga manusia untuk melakukan tugas yang membutuhkan waktu dalam proses penyelesaiannya dan bersifat repetitif perlahan dikurangi dan digantikan dengan sistem yang dapat berjalan secara mandiri. Contoh dari hal yang membutuhkan waktu dalam proses penyelesaiannya dan bersifat repetitif adalah pekerjaan rumah tangga.

Baru-baru ini penggunan robot servis otonom, khususnya robot pembersih debu otonom, sangat diminati karena mempermudah pengguna dalam menyelesaikan pekerjaan rumah tangga. Robot servis jenis ini juga dapat mencegah dan mengurangi kesalahan dalam pengerjaan pekerjaan rumah tangga akibat terjadinya human error yang disebabkan oleh tingkat akumulasi kelelahan pada penguna.

Seiring berkembangnya teknologi robotika, penambahan fungsi kendali baik secara langsung maupun tidak langsung pada peralatan elektronika merupakan salah satu faktor yang penting. Fungsi sistem kendali pada aplikasi elektronika, khususnya robot servis, memudahkan pengguna untuk memberikan perintah spesifik kepada robot. Salah satu contoh dari pengunaan fungsi kendali ini adalah pengunaan tombol dan remote-control pada peralatan elektronika. Namun, pengunaan fungsi kendali yang sekarang ada di pasaran memiliki keterbatasan dalam jarak pengunaanya. Pengunaan tombol sebagai fungsi kendali mengharuskan pengguna untuk berada di lokasi robot servis, sedangkan pengunaan remotecontrol berbasis infra merah mengharuskan pengguna untuk berada di sekitar lokasi robot servis dengan jarak kurang dari $10 \mathrm{~m}$ untuk mengendalikan robot.

Maka dari itu, dirancang dan dibangun sebuah sistem pengendalian jarak jauh robot servis berbasis internet of things (IoT). Dengan sistem pengendali jarak jauh berbasis internet of things, diharapkan dapat memudahkan pengguna dalam mengendalikan robot servis, dimana pengguna dapat mengendalikan robot servis dimana saja mereka berada selama pengguna memiliki akses pada jaringn internet.

\section{PERANCANGAN SISTEM}

Tujuan utama dari sistem adalah untuk melakukan komunikasi antara pengguna dan sistem kendali melalui jaringan internet. Sistem kendali tersebut akan digunakan untuk mengendalikan robot servis sesuai dengan perintah yang diinginkan oleh pengguna. Selain memberikan perintah kepada sistem kendali baik perintah otonom maupun perintah yang dipandu pengguna, pengguna juga dapat memonitoring kondisi lingkungan sekitar melalui tampilan citra yang dikirimkan oleh kamera kepada sistem. Ilustrasi sistem kendali jarak jauh berbasis internet of things dapat dilihat pada gambar1.

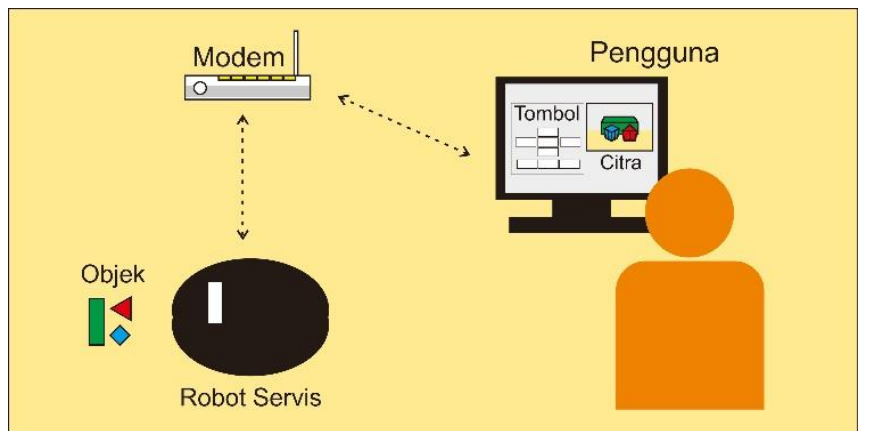

Gambar 1 Ilustrasi kendali jarak jauh robot servis berbasis Internet of Things.

Sistem yang dirancang untuk memudahkan pengguna dalam mengendalikan robot servis melalui peralatan berbasis jaringan internet ini, menggunakan robot servis pembersih debu otonom sebagai aktuator, arduino dan raspberry pi sebagai sistem pemrosesan, dan jaringan internet sebagai media komunikasi. Robot pembersih debu otonom bertindak 
sebagai aktuator dari sistem dimana robot servis akan dikendalikan oleh penguna melalui unit pemrosesan. Raspberry pi sebagai unit pemrosesan menunggu perintah dari pengguna melalui media internet dan meruskan hasil pemrosesan kepada arduino untuk dikonversi menjadi sinyal inframerah yang sesuai untuk mengendalikan aktuator. Internet berperan sebagai media komunikasi yang menghubungkan sistem dengan peralatan berbasis jaringan internet milik pengguna menggunakan Internet Protocol (IP) [1]. Konsep keseluruhan dari perancangan sistem kendali jarak jauh ini dapat digambarkan dalam diagram blok kendali jarak jauh robot servis pada gambar 2 .

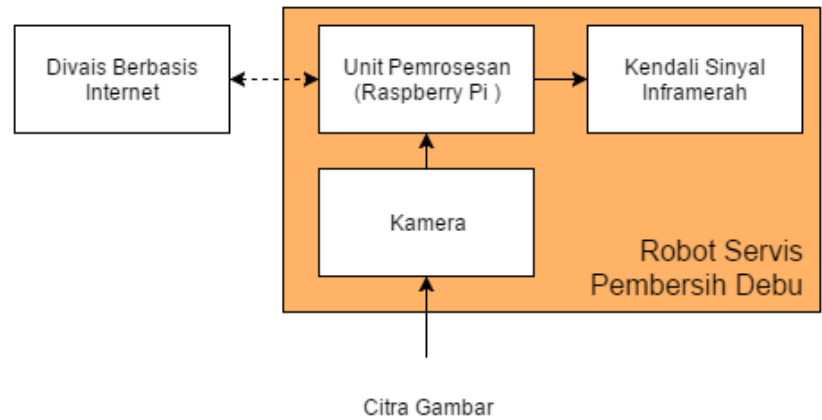

Gambar 2 Diagram Blok Sistem Kendali Jarak Jauh Berbasis Internet of Things.

\section{A. Perancangan Robot Servis Pembersih Debu}

Robot servis berupa robot pembersih debu otonom dirancang dengan desain mekanik yang tipis dan elegan sehingga robot servis mampu menjangkau area yang sulit dibersihkan. Komponen perangkat keras yang digunakan dalam rancang bangun kendali jarak jauh berbasis internet of things pada robot servis seperti raspberry pi, arduino nano, modul kamera, dan suplai daya didesain sedemikian rupa sehingga tidak menganggu fungsionalitas robot pembersih debu otonom. Foto perangkat keras sistem kendali jarak jauh robot pembersih debu berbasis internet of things dapat dilihat pada gambar 3 .

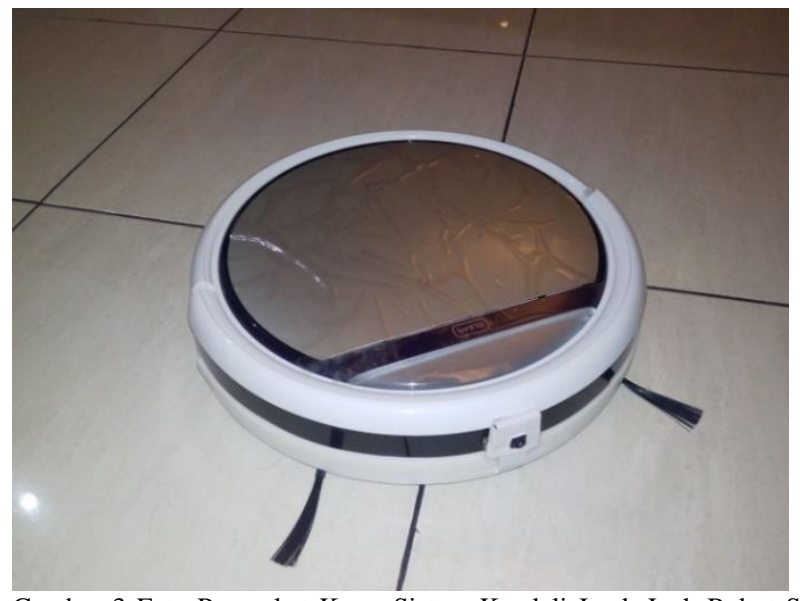

Gambar 3 Foto Perangkat Keras Sistem Kendali Jarak Jauh Robot Servis Berbasis Internet of Things.

Komponen penting dalam perancangan perangkat keras kendali jarak jauh robot servis berbasis Internet of Things sebagai berikut:
1. Modul kamera raspberry pi v1. Modul kamera ditempatkan pada bagian depan dari robot servis untuk memudahkan penguna dalam me-monitoring kondisi lingkungan yang akan dibersihkan.

2. Tempat penyimpanan debu. Tempat penyimpanan debu menyimpan debu yang disedot oleh robot servis. Tempat penyimpanan debu ditempatkan dekat dengan motor vacuum untuk mendapatkan hasil yang maksimal.

3. LM2596, modul buck converter yang digunakan untuk mengkonversi nilai tegangan dari suplai daya robot servis menjadi tegangan yang sesuai dengan suplai daya yang dibutuhkan oleh sistem kendali robot servis.

4. Single-board computer raspberry pi, Raspberry pi sebagai unit pemrosesan utama ditempatkan pada bagian tengah dari robot servis untuk memudahkan akses dari perangkat keras lainnya yang terhubung ke raspberry pi.

5. Mikrokontroler arduino nano dan emitter sinyal inframerah. Mikrokontroler arduino dan emiiter sinyal inframerah sebagai unit kendali robot servis ditempatkan di bagian belakang robot servis dekat dengan receiver sinyal inframerah sehingga memudahkan proses kendali robot servis.

Diagram keseluruhan komponen perangkat keras sistem kendali jarak jauh robot servis berbasis Internet of Things dapat dilihat pada gambar 4.

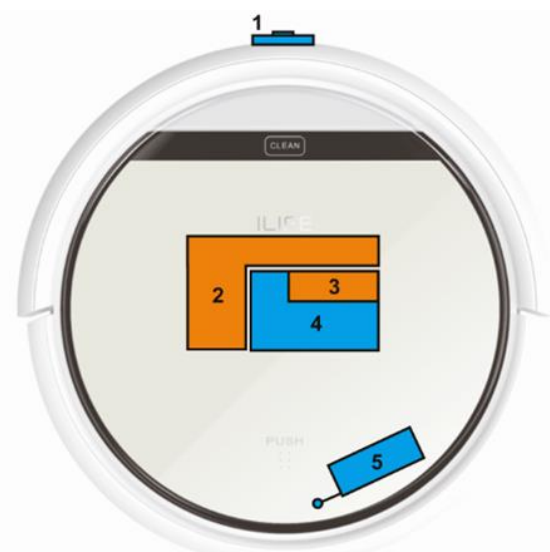

Gambar 4 Diagram perangkat keras sistem kendali jarak jauh robot servis berbasis Internet of Things.

\section{B. Perancangan Unit Pemrosesan}

Perancangan unit pemrosesan pada kendali jarak jauh robot servis berbasis Internet of Things bertujuan untuk melakukan proses servis web-server, pengambilan citra, dan antarmuka web-page. Alur kerja dari unit pemrosesan pada sistem kendali jarak jauh robot servis berbasis Internet of Things sebagai berikut:

1. Saat sistem dinyalakan, sistem akan mengaktifkan driver kamera dan servis perangkat lunak web-server yang sudah terintegrasi dengan raspberry pi.

2. Server membaca permintaan web-page dari pengguna yang telah terhubung melalui jaringan internet. Jika server telah menerima permintaan web-page dari pengguna, maka server akan mencari permintaan webpage pada hardisk server dan menampilkan web-page ke layar pengguna. Jika belum ada permintaan web-page 
dari pengguna, maka server akan terus membaca permintaan web-page [2].

3. Setelah server mengirimkan dan menampilkan antarmuka web-page pada layar pengguna, server akan menunggu interaksi atau perintah yang dikirimkan oleh pengguna sambil menampilkan feedback berupa antarmuka citra dari kamera pada antarmuka web-page.

4. Perintah yang telah diinput oleh pengguna melalui tombol pada antarmuka web-page akan diterima oleh server dan diproses untuk mengendalikan aktuator berupa robot servis.

Diagram alur perangkat lunak sistem kendali jarak jauh robot servis berbasis Internet of Things dapat dilihat pada gambar 5 .

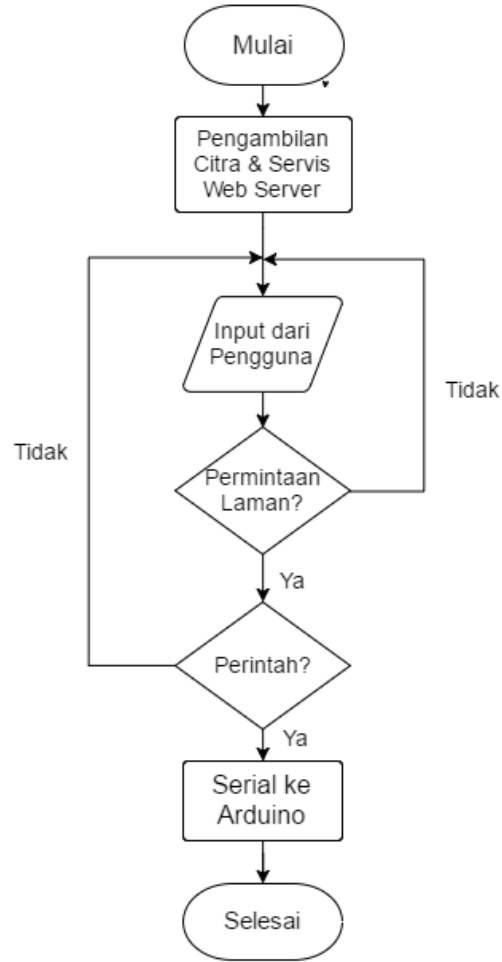

Gambar 5 Diagram alur sistem kendali jarak jauh robot servis berbasis Internet of Things.

\section{Perancangan Kendali Sinyal Inframerah}

Perancangan kendali sinyal inframerah bertujuan untuk mengendalikan robot servis melalui sinyal inframerah yang telah di-encode. Perancangan kendali sinyal inframerah dilakukan pada mikrokontroller arduino nano dengan emitter sinyal inframerah terhubung ke pin D3 [3]. Alur kerja pada perancangan kendali sinyal inframerah sebagai berikut:

1. Saat sistem kendali sinyal inframerah diaktifkan, mikrokontroler arduino nano yang mendapat suplai daya dari single-board computer raspberry pi akan membaca data serial yang akan dikirimkan oleh single-board computer raspberry pi melalui kabel serial.

2. Jika ada perintah yang dikirimkan oleh single-board computer raspberry pi, mikrokontroler arduino nano akan memproses perintah dengan mencocokan perintah dengan daftar kode inframerah yang terdapat dalam memori arduino.
3. Jika tidak ada perintah yang dikirimkan oleh singleboard computer raspberry pi, maka mikokontroler akan menunggu hingga data serial dari single-board computer raspberry pi dikirimkan.

4. Setelah memdapatkan kode inframerah yang sesuai, mikrokontroler arduino nano akan mendekode sinyal inframerah dan dikirimkan ke emitter sinyal inframerah melalui pin D3.

Adapun tabel kode sinyal inframerah yang akan digunakan untuk proses dekodifikasi adalah:

Tabel 1

Kode Sinyal Inframerah

\begin{tabular}{ccc}
\hline \hline Perintah & Kode Hex & Tipe Dekodifikasi \\
\hline Clean & 2AA22DD & NEC 32 bits \\
Down & 2AA55AA & NEC 32 bits \\
Right & 2AA6699 & NEC 32 bits \\
Left & 2AA44BB & NEC 32 bits \\
Spot-Clean & 2AA33CC & NEC 32 bits \\
Home & 2AA7788 & NEC 32 bits \\
Edge-Clean & 2AA8877 & NEC 32 bits \\
\hline \hline
\end{tabular}

\section{HASIL \& ANALISA}

\section{A. Pengujian Kendali Jarak Jauh}

Pengujian yang dilakukan pada pengujian kendali jarak jauh bertujuan untuk mengetahui keandalan kendali jarak jauh berbasis internet of things. Pengujian dilakukan dengan memberikan perintah kendali secara spesifik melalui perangkat berbasis internet seperti komputer dan smartphone yang terhubung ke sistem melalui jaringan internet.

Pengujian dilakukan dengan menggunakan jaringan lokal (localhost) untuk meminimalisir ganguan yang terjadi karena konfigurasi jaringan. Pengujian dimulai dengan memberikan perintah melalui tombol pada web-page secara spesifik dengan pengujian pada setiap perintah dilakukan sebanyak sepuluh kali. Dari pengujian tersebut didapat data-data sebagai berikut:

Tabel 2

Tabel Pengujian Kendali Jarak Jauh

\begin{tabular}{|c|c|c|c|}
\hline No & Perintah & $\begin{array}{c}\text { Tingkat } \\
\text { Keberhasilan }\end{array}$ & Keterangan \\
\hline 1 & Clean & $100 \%$ & $\begin{array}{l}\text { Robot membersihkan } \\
\text { ruangan }\end{array}$ \\
\hline 2 & $U p$ & $100 \%$ & Robot bergerak maju \\
\hline 3 & Down & $100 \%$ & Robot bergerak mundur \\
\hline 4 & Right & $100 \%$ & $\begin{array}{l}\text { Robot berputar } 45^{\circ} \mathrm{ke} \\
\text { kanan }\end{array}$ \\
\hline 5 & Left & $100 \%$ & Robot berputar $45^{\circ}$ ke kiri \\
\hline 6 & Spot-Clean & $100 \%$ & $\begin{array}{l}\text { Robot membersihkan } \\
\text { ruangan }\end{array}$ \\
\hline 7 & Home & $100 \%$ & Robot kembali ke dock \\
\hline
\end{tabular}




\begin{tabular}{cccl}
\hline \hline 8 & Wall-Clean & $100 \%$ & $\begin{array}{l}\text { Robot membersihkan } \\
\text { ruangan }\end{array}$ \\
9 & View-Left & $100 \%$ & $\begin{array}{l}\text { Robot berputar } 360^{\circ} \\
\text { ke kiri }\end{array}$ \\
10 & $\begin{array}{l}\text { Keep } \\
\text { Forward }\end{array}$ & $100 \%$ & $\begin{array}{l}\text { Robot bergerak maju } \\
\text { Robot berputar } 360^{\circ} \\
\text { ke kanan }\end{array}$ \\
\hline \hline
\end{tabular}

Dari data diatas dapat disimpulkan bahwa kendali jarak jauh dalam rancang bangun tugas akhir ini memiliki tingkat keberhasilan yang tinggi yaitu sebesar $100 \%$ pada jaringan internet lokal (localhost).

\section{B. Pengujian Responsivitas Kendali Jarak Jauh}

Pengujian yang dilakukan pada pengujian konektivitas kendali jarak jauh bertujuan untuk mengetahui responsibilitas sistem pada jaringan berbasis TCP/IP (Transmission Control Protocol/Internet Protocol). Pengujian pada responsivitas sistem ini dilakukan dengan melakukan pengukuran perbedaan waktu pada saat perintah diberikan oleh pengguna melalui antarmuka web-page dengan respon yang diberikan oleh robot servis. Grafik hasil pengujian responsivitas kendali jarak jauh dapat dilihat pada gambar 6.

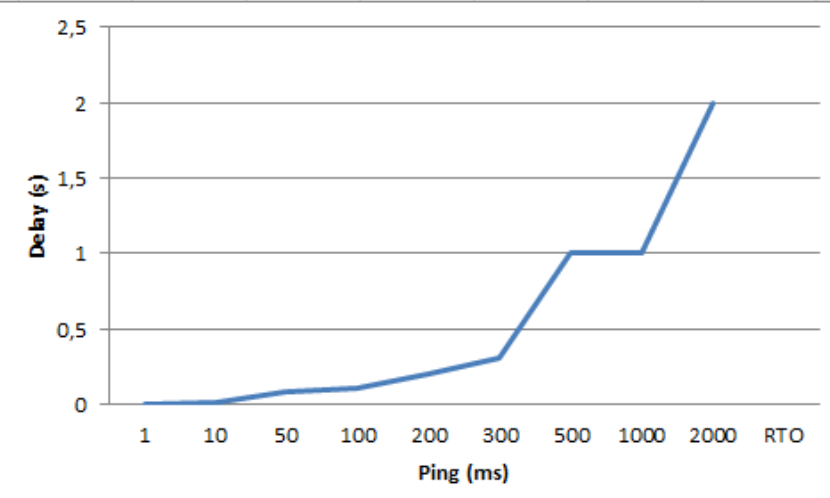

Gambar 6 Grafik hasil pengujian responsivitas kendali jarak jauh berbasis Internet of Things.

Dari data diatas dapat disimpulkan bahwa keterlambatan respon sistem terhadap perintah yang diberikan oleh pengguna berbanding lurus dengan kenaikan PING (Packet Internet Gopher) pada jaringan TCP/IP. Dimana setiap kenaikan ping sebesar 1000ms menghasilkan keterlambatan sebesar $1 \mathrm{~s}$.

\section{Pengujian User-Guided Control}

Pengujian pada pengujian user-guided control bertujuan untuk mengetahui ketepatan fungsi pada user-guided control. Pengujian pada kendali jarak jauh yang dipandu oleh pengguna ini dilakukan dengan melakukan perhitungan kesalahan antara hasil yang diinginkan pada user-guided control dan hasil yang diperoleh saat pengujian. Pengujian user-guided control dibagi menjadi pengujian pada kendali view-left, pengujian pada kendali keep forward, dan pengujian pada kendali view-right.

- Pengujian View-Left

Pengujian pada user-guided control view-left bertujuan untuk mengetahui ketepatan robot servis saat diberikan perintah view-left oleh pengguna, dimana robot akan berputar sebesar $360^{\circ}$ ke kiri untuk memberikan tampilan citra lingkungan di sekitar robot servis dimulai dari bagian kiri robot. Selain ketepatan robot servis dalam berputar $360^{\circ}$ ke kiri, pengujian terhadap user-guided control view-left juga meliputi kendali robot, dimana robot servis dapat dihentikan oleh pengguna saat berputar dengan menekan kembali tombol view-left atau menekan tombol clean pada antarmuka webpage. Berikut adalah data-data hasil pengujian view-left:

Tabel 3

Pengujian View-Left

\begin{tabular}{|c|c|c|c|c|}
\hline No & Perintah & Hasil & Error & Keterangan \\
\hline 1 & View-Left & $358^{\circ}$ & $2^{\circ}$ & $\begin{array}{l}\text { Robot dapat } \\
\text { dihentikan saat } \\
\text { berputar }\end{array}$ \\
\hline 2 & View-Left & $359^{\circ}$ & $1^{\circ}$ & $\begin{array}{l}\text { Robot dapat } \\
\text { dihentikan saat } \\
\text { berputar }\end{array}$ \\
\hline 3 & View-Left & $365^{\circ}$ & $5^{\circ}$ & $\begin{array}{l}\text { Robot dapat } \\
\text { dihentikan saat } \\
\text { berputar }\end{array}$ \\
\hline 4 & View-Left & $360^{\circ}$ & $0^{\circ}$ & $\begin{array}{l}\text { Robot dapat } \\
\text { dihentikan saat } \\
\text { berputar }\end{array}$ \\
\hline 5 & View-Left & $359^{\circ}$ & $1^{\circ}$ & $\begin{array}{l}\text { Robot dapat } \\
\text { dihentikan saat } \\
\text { berputar }\end{array}$ \\
\hline 6 & View-Left & $358^{\circ}$ & $2^{\circ}$ & $\begin{array}{l}\text { Robot dapat } \\
\text { dihentikan saat } \\
\text { berputar }\end{array}$ \\
\hline 7 & View-Left & $360^{\circ}$ & $0^{\circ}$ & $\begin{array}{l}\text { Robot dapat } \\
\text { dihentikan saat } \\
\text { berputar }\end{array}$ \\
\hline 8 & View-Left & $358^{\circ}$ & $2^{\circ}$ & $\begin{array}{l}\text { Robot dapat } \\
\text { dihentikan saat } \\
\text { berputar }\end{array}$ \\
\hline 9 & View-Left & $360^{\circ}$ & $0^{\circ}$ & $\begin{array}{l}\text { Robot dapat } \\
\text { dihentikan saat } \\
\text { berputar }\end{array}$ \\
\hline 10 & View-Left & $358^{\circ}$ & $2^{\circ}$ & $\begin{array}{l}\text { Robot dapat } \\
\text { dihentikan saat } \\
\text { berputar }\end{array}$ \\
\hline
\end{tabular}

Dari data pada diatas dapat disimpulkan bahwa kendali jarak jauh view-left yang dipandu oleh pengguna memiliki ketidaktepatan hasil saat berputar dengan rata-rata sebesar $1.5^{\circ}$.

\section{- Pengujian Keep-Forward}

Pengujian pada user-guided control keep forward bertujuan untuk mengetahui keandalan robot servis saat diberikan perintah keep forward oleh pengguna, dimana robot servis akan terus bergerak maju hingga pengguna menekan kembali tombol keep forward atau menekan tombol clean pada antarmuka web-page. Berikut adalah data-data hasil pengujian keep forward:

Tabel 4

Pengujian Keep-Forward

\begin{tabular}{clcl}
\hline \hline No & Perintah & Hasil & \multicolumn{1}{c}{ Keterangan } \\
\hline 1 & $\begin{array}{l}\text { Keep } \\
\text { Forward }\end{array}$ & $\checkmark$ & $\begin{array}{l}\text { Robot bergerak maju dan } \\
\text { dapat dihentikan }\end{array}$ \\
2 & $\begin{array}{l}\text { Keep } \\
\text { Forward }\end{array}$ & $\checkmark$ & $\begin{array}{l}\text { Robot bergerak maju dan } \\
\text { dapat dihentikan }\end{array}$ \\
\hline \hline
\end{tabular}




\begin{tabular}{|c|c|c|c|}
\hline 3 & $\begin{array}{l}\text { Keep } \\
\text { Forward }\end{array}$ & $x$ & $\begin{array}{l}\text { Robot bergerak maju dan } \\
\text { dapat dihentikan }\end{array}$ \\
\hline 4 & $\begin{array}{l}\text { Keep } \\
\text { Forward }\end{array}$ & $\checkmark$ & $\begin{array}{l}\text { Robot bergerak maju dan } \\
\text { dapat dihentikan }\end{array}$ \\
\hline 5 & $\begin{array}{l}\text { Keep } \\
\text { Forward }\end{array}$ & $\checkmark$ & $\begin{array}{l}\text { Robot bergerak maju dan } \\
\text { dapat dihentikan }\end{array}$ \\
\hline 6 & $\begin{array}{l}\text { Keep } \\
\text { Forward }\end{array}$ & $x$ & $\begin{array}{l}\text { Robot bergerak maju dan } \\
\text { dapat dihentikan }\end{array}$ \\
\hline 7 & $\begin{array}{l}\text { Keep } \\
\text { Forward }\end{array}$ & $\checkmark$ & $\begin{array}{l}\text { Robot bergerak maju dan } \\
\text { dapat dihentikan }\end{array}$ \\
\hline 8 & $\begin{array}{l}\text { Keep } \\
\text { Forward }\end{array}$ & $\checkmark$ & $\begin{array}{l}\text { Robot bergerak maju dan } \\
\text { dapat dihentikan }\end{array}$ \\
\hline 9 & $\begin{array}{l}\text { Keep } \\
\text { Forward }\end{array}$ & $\checkmark$ & $\begin{array}{l}\text { Robot bergerak maju dan } \\
\text { dapat dihentikan }\end{array}$ \\
\hline 10 & $\begin{array}{l}\text { Keep } \\
\text { Forward }\end{array}$ & $\checkmark$ & $\begin{array}{l}\text { Robot bergerak maju dan } \\
\text { dapat dihentikan }\end{array}$ \\
\hline
\end{tabular}

Dari data diatas dapat disimpulkan bahwa kendali jarak jauh keep forward yang dipandu oleh pengguna memiliki tingkat keandalan yang cukup tinggi yaitu sebesar $80 \%$.

\section{- Pengujian View-Right}

Pengujian pada user-guided control view-right bertujuan untuk mengetahui ketepatan robot servis saat diberikan perintah view-right oleh pengguna, dimana robot akan berputar sebesar $360^{\circ}$ ke kanan untuk memberikan tampilan citra lingkungan di sekitar robot servis dimulai dari bagian kanan robot. Selain ketepatan robot servis dalam berputar $360^{\circ}$ ke kanan, pengujian terhadap user-guided control view-right juga meliputi kendali robot, dimana robot servis dapat dihentikan oleh pengguna saat berputar dengan menekan kembali tombol view-right atau menekan tombol clean pada antarmuka web-page. Berikut adalah data-data hasil pengujian view-right:

Tabel 5

Pengujian View-Right

\begin{tabular}{|c|c|c|c|c|}
\hline No & Perintah & Hasil & Error & Keterangan \\
\hline 1 & View-Right & $360^{\circ}$ & $0^{\circ}$ & $\begin{array}{l}\text { Robot dapat } \\
\text { dihentikan saat } \\
\text { berputar }\end{array}$ \\
\hline 2 & View-Right & $360^{\circ}$ & $0^{\circ}$ & $\begin{array}{l}\text { Robot dapat } \\
\text { dihentikan saat } \\
\text { berputar }\end{array}$ \\
\hline 3 & View-Right & $365^{\circ}$ & $5^{\circ}$ & $\begin{array}{l}\text { Robot dapat } \\
\text { dihentikan saat } \\
\text { berputar }\end{array}$ \\
\hline 4 & View-Right & $358^{\circ}$ & $2^{\circ}$ & $\begin{array}{l}\text { Robot dapat } \\
\text { dihentikan saat } \\
\text { berputar }\end{array}$ \\
\hline 5 & View-Right & $360^{\circ}$ & $0^{\circ}$ & $\begin{array}{l}\text { Robot dapat } \\
\text { dihentikan saat } \\
\text { berputar }\end{array}$ \\
\hline 6 & View-Right & $363^{\circ}$ & $3^{\circ}$ & $\begin{array}{l}\text { Robot dapat } \\
\text { dihentikan saat } \\
\text { berputar }\end{array}$ \\
\hline 7 & View-Right & $359^{\circ}$ & $1^{\circ}$ & $\begin{array}{l}\text { Robot dapat } \\
\text { dihentikan saat } \\
\text { berputar }\end{array}$ \\
\hline 8 & View-Right & $360^{\circ}$ & $0^{\circ}$ & $\begin{array}{l}\text { Robot dapat } \\
\text { dihentikan saat } \\
\text { berputar }\end{array}$ \\
\hline 9 & View-Right & $362^{\circ}$ & $2^{\circ}$ & $\begin{array}{l}\text { Robot dapat } \\
\text { dihentikan saat } \\
\text { berputar }\end{array}$ \\
\hline
\end{tabular}

\begin{tabular}{llll}
\hline \hline View-Right & $360^{\circ}$ & $0^{\circ}$ & $\begin{array}{l}\text { Robot dapat } \\
\text { dihentikan saat } \\
\text { berputar }\end{array}$ \\
\hline \hline
\end{tabular}

Dari data diatas dapat disimpulkan bahwa kendali jarak jauh view-right yang dipandu oleh pengguna memiliki ketidaktepatan hasil saat berputar dengan rata-rata sebesar $1.3^{\circ}$.

\section{Pengujian Antarmuka Web-page}

Pengujian pada pengujian antarmuka web-page bertujuan untuk mengetahui kompatibilitas antarmuka web-page pada berbagai browser dan peralatan berbasis internet. Pengujian pada antarmuka web-page dilakukan dengan mengakses halaman web-page pada peralatan dan browser yang diuji. Pengujian pada antarmuka web-page dibagi menjadi pengujian antarmuka web-page pada komputer dan pengujian antarmuka web-page pada smartphone.

- Pengujian pada komputer

Pengujian antarmuka web-page pada komputer bertujuan untuk mengetahui kompatibilitas antarmuka web-page pada berbagai browser di komputer. Pengujian dilakukan dengan mengakses halaman web-page pada komputer melalui berbagai browser. Berikut adalah data-data pengujian antarmuka web-page pada komputer:

Tabel 6

Pengujian pada komputer

\begin{tabular}{|c|c|c|c|}
\hline No & Browser & Kompatibilitas & Keterangan \\
\hline 1 & $\begin{array}{l}\text { Internet } \\
\text { Explorer }\end{array}$ & $\begin{array}{c}\text { Tidak } \\
\text { Kompatibel }\end{array}$ & $\begin{array}{l}\text { Tampilan kamera tidak } \\
\text { berfungsi dengan baik }\end{array}$ \\
\hline 2 & $\begin{array}{l}\text { Google } \\
\text { Chrome }\end{array}$ & Kompatibel & $\begin{array}{l}\text { Antarmuka web-page } \\
\text { ditampilkan dengan baik }\end{array}$ \\
\hline 3 & $\begin{array}{l}\text { Mozilla } \\
\text { Firefox }\end{array}$ & Kompatibel & $\begin{array}{l}\text { Antarmuka web-page } \\
\text { ditampilkan dengan baik }\end{array}$ \\
\hline 4 & Opera & Kompatibel & $\begin{array}{l}\text { Antarmuka web-page } \\
\text { ditampilkan dengan baik }\end{array}$ \\
\hline
\end{tabular}

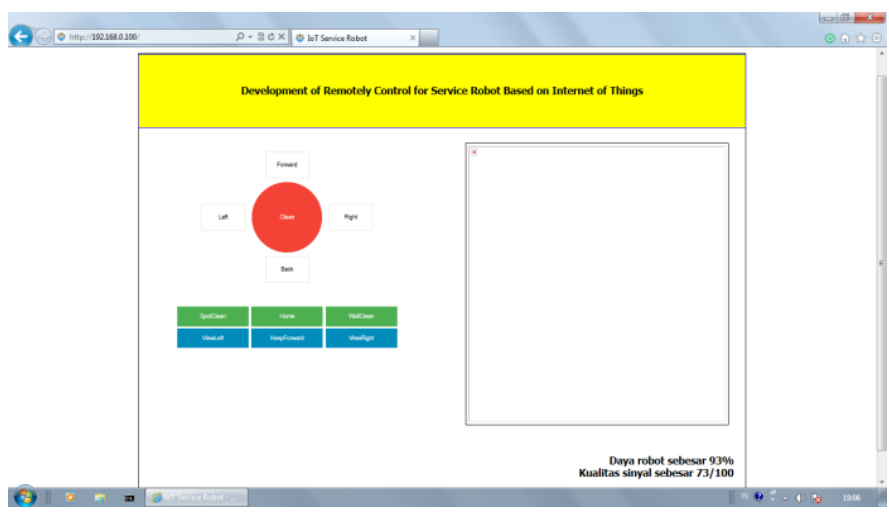

Gambar 7 Antarmuka webpage pada Internet Explorer 


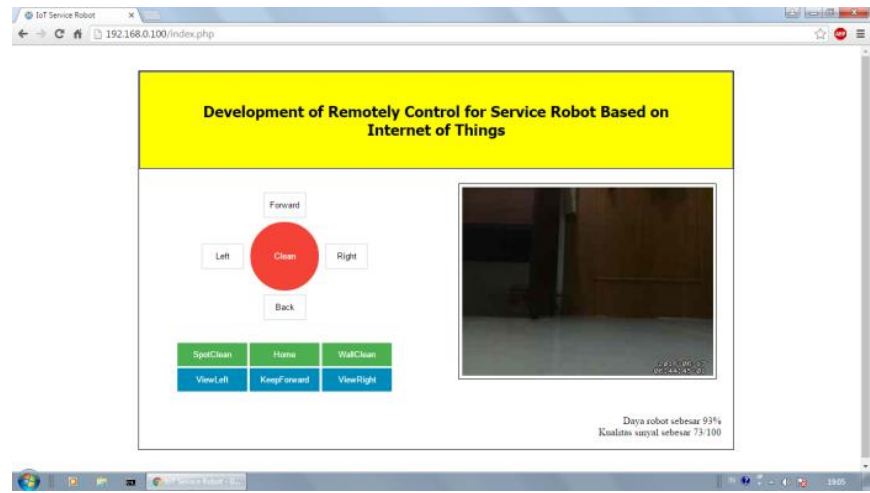

Gambar 8 Antarmuka webpage pada Google Chrome

Dari data diatas dapat disimpulkan bahwa tampilan antarmuka web-page pada berbagai browser di komputer tidak sepenuhnya kompatibel. Hal ini dikarenakan Internet Explorer sebagai default browser di sistem operasi Microsoft tidak mendukung adanya layanan mjpeg yang digunakan untuk menampilkan tampilan kamera.

\section{- Pengujian pada smartphone}

Pengujian antarmuka web-page pada smartphone bertujuan untuk mengetahui kompatibilitas antarmuka web-page pada berbagai browser di smartphone. Pengujian dilakukan dengan mengakses halaman web-page pada smartphone melalui berbagai browser. Berikut adalah data-data pengujian antarmuka web-page pada smartphone:

Tabel 7

Pengujian pada smartphone

\begin{tabular}{|c|c|c|c|}
\hline No & Browser & Kompatibilitas & Keterangan \\
\hline 1 & $\begin{array}{l}\text { Mozilla } \\
\text { Firefox }\end{array}$ & Kompatibel & $\begin{array}{l}\text { Antarmuka web-page } \\
\text { ditampilkan dengan } \\
\text { baik oleh browser }\end{array}$ \\
\hline 2 & $\begin{array}{l}\text { Default } \\
\text { Browser }\end{array}$ & $\begin{array}{c}\text { Tidak } \\
\text { Kompatibel }\end{array}$ & $\begin{array}{l}\text { Tampilan kamera dan } \\
\text { styling tombol pada } \\
\text { antarmuka web-page } \\
\text { tidak } \quad \text { berfungsi } \\
\text { dengan baik }\end{array}$ \\
\hline 3 & $\begin{array}{l}\text { Google } \\
\text { Chrome }\end{array}$ & Kompatibel & $\begin{array}{l}\text { Antarmuka web-page } \\
\text { ditampilkan dengan } \\
\text { baik oleh browser }\end{array}$ \\
\hline 4 & Opera & $\begin{array}{c}\text { Tidak } \\
\text { Kompatibel }\end{array}$ & $\begin{array}{l}\text { Tampilan kamera dan } \\
\text { styling tombol pada } \\
\text { antarmuka web-page } \\
\text { tidak berfungsi } \\
\text { dengan baik }\end{array}$ \\
\hline 5 & $\begin{array}{c}\mathrm{UC} \\
\text { Browser }\end{array}$ & $\begin{array}{c}\text { Tidak } \\
\text { Kompatibel }\end{array}$ & $\begin{array}{l}\text { Tampilan kamera } \\
\text { pada antarmuka web- } \\
\text { page tidak berfungsi } \\
\text { dengan baik }\end{array}$ \\
\hline 6 & $\begin{array}{c}\mathrm{CM} \\
\text { Browser }\end{array}$ & $\begin{array}{c}\text { Tidak } \\
\text { Kompatibel }\end{array}$ & $\begin{array}{l}\text { Tampilan kamera dan } \\
\text { styling tombol pada } \\
\text { antarmuka web-page } \\
\text { tidak berfungsi } \\
\text { dengan baik }\end{array}$ \\
\hline
\end{tabular}

Dari data diatas dapat disimpulkan bahwa tampilan antarmuka web-page pada berbagai browser di smartphone tidak sepenuhnya kompatibel. Hal ini dikarenakan beberapa browser seperti Default Browser, UC Browser, CM Browser, dan Opera tidak mendukung adanya layanan mjpeg dan beberapa styling pada css yang digunakan untuk menampilkan tampilan kamera dan memperhalus tampilan web-page.

\section{KESIMPULAN DAN SARAN}

Rancang bangun kendali jarak jauh robot servis berbasis Internet of Things menggunakan mikrokontroller arduino dan single-board computer raspberry pi sebagai unit pemrosesan. Berikut adalah kesimpulan dari perancangan sistem kendali jarak jauh berbasis Internet of Things :

1. Berdasarkan data yang diperoleh dari pengujian sistem, dapat disimpulkan bahwa kendali jarak jauh berbasis internet of things memiliki tingkat kehandalan yang tinggi yaitu sebesar $100 \%$. Dengan menggunakan spesifikasi sistem yang digunakan pada tugas akhir ini, robot servis dapat menjalankan seluruh perintah yang diinputkan oleh pengguna.

2. User-guided control sebagai kendali jarak jauh yang dipandu oleh pengguna memiliki ketepatan fungsi yang baik dimana kendali view left memiliki kesalahan sebesar $1.5^{\circ}$, kendali keep forward tidak memiliki tingkat keberhasilan sebesar $80 \%$, dan kendali view-right memiliki kesalahan sebesar $1.3^{\circ}$.

3. Antarmuka web-page dari server yang diakses oleh pengguna melalui peralatan berbasis internet baik komputer maupun smartphone tidak seluruhnya kompatibel dengan berbagai layanan browser. Layanan browser yang kompatibel dengan tugas akhir ini adalah Google Chrome dan Mozilla Firefox yang dapat diakses melalui komputer maupun smartphone.

Adapun beberapa saran untuk perbaikan dan pengembangan tugas akhir sebagai berikut:

1. Robot servis yang digunakan pada tugas akhir ini diharapkan dapat dikembangkan lebih lanjut sehingga mempermudah pengguna dalam pengunaan kendali jarak jauh berbasis internet of things dalam kehidupan seharihari.

2. Sistem yang digunakan pada tugas akhir ini memerlukan biaya yang cukup besar. Dianjurkan untuk mencari alternatif mikrokontroler lain untuk mengendalikan robot servis berbasis internet of things sehingga kendali jarak jauh ini dapat dinikmati oleh masyarakat luas.

\section{UCAPAN TERIMA KASIH}

Penulis A.S. mengucapkan terima kasih kepada:

1. Bapak Dr. Ir. Djoko Purwanto, M.Eng. dan Bapak Rudy Dikairono, S.T., M.T. selaku dosen pembimbing Tugas Akhir yang telah memberi bimbingan, nasehat, dan kemudahan dalam penyelesaian Tugas Akhir ini,

2. Bapak Dr. Eng. Ardyono Priyadi, S.T., M.Eng. selaku Ketua Jurusan dan dosen penulis,

3. Bapak Andreas Agung dan segenap karyawan PT. Hartono Istana Teknologi yang telah memberikan masukan, saran, dan arahan dalam pembuatan Tugas Akhir,

4. Orang tua dan saudara penulis yang telah memberi dukungan material dan moril yang berlimpah.

5. Keluarga asisten Laboratorium Elektronika yang ikut membantu dan menemani dalam segala hal.

6. Teman-teman satu angkatan 2012 reguler Elektro yang 
menjadi teman berbagi cerita dalam suka maupun duka.

7. Serta semua pihak yang telah membantu penulis dalam menyelesaikan Tugas Akhir ini.

\section{DAFTAR PUSTAKA}

[1] Waher, Peter, "Learning Internet of Thing", Packt Publishing Ltd., Brimingham, 2015.

[2] Nixon, Robin, "Learning PHP, My SQL, JavaScript, CSS \& HTML5", O'Reilly Media, Inc., California, 2014

[3] Tasi, Janie, "Technical Data Sheet 5mm Infrared LED”, Everlight Electronics Co., Ltd., Taiwan, 2005. 